\title{
Bir Mobilya Üretim Tesisinde İş Analizi ve Benzetim Uygulaması ile Süreç Verimliliğinin Artırılması
}

\author{
Abdullah Sütçü ${ }^{1 *}$, Osman Karşıyaka², Mustafa Emrah Burhan ${ }^{3}$ \\ ${ }^{1}$ Isparta Uygulamalı Bilimler Üniversitesi, Orman Fakültesi, Orman Endüstri Mühendisliği Bölümü, Isparta, Türkiye (ORCID: 0000-0003-4200-917X) \\ ${ }^{2}$ Konfor Dayanıklı Tüketim Malları Mobilya Deri Tekstil İnşaat Turizm San.ve Tic.A.Ş., İzmir, Türkiye (ORCID: 0000-0002-1668-5484) \\ ${ }^{3}$ Süleyman Demirel Üniversitesi, Mühendislik Fakültesi, Endüstri Mühendisliği Bölümü, Isparta, Türkiye (ORCID: 0000-0001-6913-707X)
}

(Illk Geliş Tarihi 22 Ağustos 2019 ve Kabul Tarihi 11 Eylül 2019)

(DOI: 10.31590/ejosat.609563)

ATIF/REFERENCE: Sütçü, A., Karşıyaka, O. \& Burhan, M. E. (2019). Bir Mobilya Üretim Tesisinde İş Analizi ve Benzetim Uygulaması ile Süreç Verimliliğinin Artırılması. Avrupa Bilim ve Teknoloji Dergisi, (17), 45-57.

$\ddot{\mathbf{O} z}$

Türkiye mobilya endüstrisi, dış ticaret fazlası veren, sürekli büyüyen ve ülke sathına yayılmakla birlikte yüksek istihdam imkânı sağlayan ve böylece bölgeler arası eşitsizliği gidermeye yönelik misyonu yerine getiren önemli bir sektördür. Ancak, sektörde faaliyet gösteren işletmelerin küresel pazarlarda rekabet edebilmeleri ve faaliyetlerini devam ettirebilmeleri için maliyetleri düşürmekle birlikte verimliliği ve kaliteyi yükselten sürekli iyileşme tekniklerini de kullanmaları her geçen gün daha da zorunlu hale gelmektedir. Bu kapsamda gerçekleştirilen çalışmada; büyük ölçekli bir mobilya fabrikasının bazı üretim süreçleri ele alınanarak verimliliğin ve etkinliğin artırılmasına yönelik yeniden organizasyon faaliyetleri örnek uygulamalar olarak gerçekleştirilmiş, üretim sistemin etkinliğini düşüren başlıca sorunlar literatür ışığında ve imalat ortamında gerçekleştirilen gözlemler yoluyla irdelenerek, imalat temin süresi, süreç içi stok değeri, kapasite kullanım oranları ve diğer performans göstergelerinin iyileştirilmesi, verimliliğin ve etkinliğin arttırılması hedeflenmiştir. Geliştirme-iyileştirme modelleri olarak imalat atölyesine ait iş ve işlemlerin gerçekleştiği darboğaza sebep olan iş istasyonlarında iş zenginleştirme, iş basitleştirme ve iş değişimi gibi yeniden organizasyon tedbirleri uygulanmış, süreç içi stokların azaltılması ve katma değer oluşturmayan faaliyetlerin ortadan kaldırılması sağlanmıştır. Bununla birlikte, ele alınan ürünün üretim sürecine ait iş ve zaman etüdleri REFA formları kullanılarak gerçekleştirilmiş, iş analizi ile öncesi-sonrası durumlar çalışma içerisinde paylaşıllmıştır. Yeniden organizasyon ve sistemin geliştirilmesi için ilgili ürüne ait sürecin benzetim modeli Arena 14.0 benzetim yazılımı üzerinde oluşturulmuştur. Simülasyon modelinde faaliyetlere ait hazırlık ve işlem zamanları stokastik veri, iş yükleri, makina ve personel sayıları, parti büyüklükleri ile çalışma süreleri deterministik veri olarak ele alınmıştır. Çalışma sonucunda; çevrim zamanında 34dk kazançla üretim verimliliğinde \%10'luk artış, iş istasyonlarında farklı olmakla birlikte kapasite kullanım oranlarında iyileşme ve zamanında teslim edilebilir ürün oranında artış sağlanmıştır. Ancak, bu kazanımların sürekliliği; kurumsal kültürün yerleşmesi ve iyileştirme çalışmalarının devamlılığına bağlıdır.

Anahtar Kelimeler: Modelleme, İş Etüdü, Arena, Kapasite Kullanım Oranı, Orman Endüstri Mühendisliği

\section{Improving Process Efficiency in a Furniture Production Facility with Work Analysis and Simulation: Case Study}

\begin{abstract}
Turkey's furniture industry, foreign trade surplus, steady growth, to be spread over the country and is an important sector for fulfilling the mission of reducing inequalities between regions due to the possibility of creating high levels of employment. However, it is becoming more and more necessary for companies operating in the sector to use continuous improvement techniques that increase
\end{abstract}

* Sorumlu Yazar: Isparta Uygulamalı Bilimler Üniversitesi, Orman Fakültesi, Orman Endüstri Mühendisliği Bölümü, Isparta, Türkiye, ORCID: 0000-0003-4200-917X, abdulahsutcu@,isparta.edu.tr 
productivity and quality while reducing costs in order to compete and sustain their viability in global markets. In this study; some production processes of a large-scale furniture factory were discussed and reorganization activities aimed at increasing productivity and efficiency were carried out as case study. In this study, the main problems that decrease the efficiency of the production system are examined in the light of the literature and observations made in the manufacturing environment. It is aimed to improve performance indicators such as manufacturing lead time, work in process and utilization rates. As the improvement models, job design method such as rotation, simplification, enlargement and enrichment of jobs, were applied in the workstations that caused bottleneck, and work in process (WIP) were reduced and activities that non value added were eliminated. In addition, time and motion studies related to the production process of the product discussed were carried out using REFA forms, and before and after statements were shared in the study. For the reorganization and the improvement of the system, the simulation model of the related product process was modelled on Arena 14.0 simulation software. In the simulation model, the set-up and processing times of the activities are considered as stochastic data, workloads, number of machines and personnel, lot sizes and working hours as deterministic data. After the studied observed that, increase in efficiency with 34 minutes $(10 \%)$ gain in cycle time, improvement in utilization rates and increase in on-time delivery rate, although different in workstations. However, the continuity of these gains; It depends on the establishment of corporate culture and the continuity of improvement studies.

Keywords: Modelling, Work Study, Arena, Utilization Rate, Forest Product Engineering.

\section{Giriş}

Türkiye mobilya endüstrisinin ulusal imalat sanayii içerisindeki önemi her geçen gün daha da artmaktadır. Sektör, 2018 yılında 3,1 milyar dolar döviz kazandırmış, 2,3 milyar dolar dış ticaret fazlası vermiş ve 2023 yılı için 6 milyar dolar ihracat hedefini ortaya koymuştur (Orsiad, 2019). Ulusal kalkınma için bu özellikleri yanında, ülke sathına yayılmış irili ufaklı birçok firma ile işletme sayısı açısından imalat sanayi içerisindeki dördüncü sırada yer alırken bölgeler arası ekonomik eşitsizliği gidermeye yönelik önemli bir argüman olmaya devam etmektedir. Ancak, küresel oyuncular özellikle Çin ve diğer Uzak Asya ülkelerinin hemen hemen tüm pazarlarda rekabette öne geçmeleri diğer ekonomileri olduğu gibi Türkiye mobilya endüstrisini de tehdit etmektedir.

Türkiye mobilya endüstrisinde, son 20 yıla kadar küçük atölyelerde kısıtlı üretim hacimlerinde sadece yöresel pazarlara yönelik ve yoğun insan gücü kullanılarak üretim yapılırken günümüzde ise daha yoğun bir teknoloji kullanan, markalaşmış, özgün tasarımlar üretebilen, uluslararası piyasalarda rekabet edebilen, kitlesel üretim yapma imkânlarına sahip hatlardan oluşan birçok tesis bulunmaktadır. Bu tesisler ile küresel piyasalarda rekabet avantajı elde edebilmek için, rakiplerde var olan, özellikle hammadde, enerji ve işçilik maliyetlerindeki avantajlara karşılık, özgün tasarımların ön planda olduğu katma değeri yüksek ürünleri, verimlilik ve kalite odaklı sürekli gelişme stratejileri ile gerçekleştirme zorunluluğu ortaya çıkmaktadır.

Mobilya üretimi genel itibariyle kesikli üretim sistemine sahiptir. Kesikli üretim sisteminde operasyonlar arası dengesizlikler mevcuttur. Bu dengesizliğin sebep olduğu performans kayıpları (temin sürelerinin uzunluğu, zamanında siparişin teslim edilememesi, düşük kapasite kullanım oranları vb.) ara stok miktarlarını yüksek tutarak veya etkin çizelgeleme yöntemleri ve ürün odaklı yeniden organizasyon tedbirleri ile dengeli bir üretim yapılması ile bertaraf edilebilir. Bu çalışma kapsamında, üretim sürecindeki darboğazlar iş analizi ile tespit edilmiş, süreçteki faaliyetler iş birleştirme, iş basitleştirme ve iş değişimi gibi yeniden organizasyon tedbirleri ile benzetim modelleri üzerinde uygulanılarak süreç içi stoklarının azaltılması, katma değer oluşturmayan faaliyetlerin ortadan kaldırılması ve diğer performans göstergelerinin iyileştirilmesi amaçlanmıştır.

Literatürde iş etüdü tekniklerinden yararlanılarak verimliliğin ekstra bir yatırım gerektirmeden artırılmasına yönelik birçok çalışma bulunmaktadır. Örneğin; Dizdar ve Özen (2001), bir mobilya fabrikasında üretimin kritik noktasını teşkil eden panel kesim atölyesinde bulunan yatay levha kesme iş istasyonu önünde oluşan birikmelerden dolayı üretim hattında görünen yavaşlamaları ele alarak iş etüdü çalışması yapmıştır. Yapılan çalışma sonucu metot ve zaman etüdü düzenlemeleriyle \%66,5 oranında zaman kazancı ve önemli oranda verimlilik artışı sağlamıştır.

$\mathrm{Bu}$ çalışmalar neticesinde önerilen yeniden organizasyon faaliyetlerinin işletmede bilfiil uygulanması ve sonuçlarının tecrübe edilmesi ekonomiklik ve zaman açısından her zaman tercih edilememektedir. Oluşacak maliyetler ve zaman kaybı bir çok kez karar vericilerin ikna edilmesini zorlaştırmaktadır. Bu durumda kullanılan en önemli araç ise bilgisayar destekli benzetim araçlarıdır. Benzetim destekli çalışmalar imalat sanayiinde özellikle otomotiv ve tekstil sektörlerinde yıllardır çok başarılı bir şekilde uygulanırken son yıllarda orman ürünleri endüstrisinde de azımsanmayacak düzeyde gerçekleştirilmektedir. Örneğin; emek yoğun sektörlerden biri olan mobilya endüstrisine yönelik yapılan bir çalışmada benzetim modeli üzerinde personel ve iş organizasyonu açısından değişiklikler yapılarak daha iyi performans gösteren yeni bir organizasyonel modelde daha az personel ile daha yüksek termin karşılama oranına ulaşılmıştır (Sütçü vd., 2006). Benzer bir diğer çalışmada da; kapasite planlanması, planlama sonucu personel transferi, alternatif ürün rotalama ve fazla mesai olanakları Arena simülasyon programı yardımıyla mobilya endüstrisinde bir model üzerinde uygulanmıştır (Kaya, 2001). Sütçü vd. (2011), karma hücresel düzenleme, müşteri-sipariş-ürün ve görev odaklı organizasyonel yapılanmaların performans ölçütleri üzerinde etkisini araştırmıştır. Değerlendirilen modeller üzerinde kapasite kullanım oranı açısından yaklaşık \%40’lık iyileşme sağlanmıştır. Kereste endüstrisine yönelik bir çalışmada ise; üretim sisteminin kesim işlemlerine yönelik süreç iyileştirme uygulaması yapılmıştır. Çalışmada alternatif senaryolar geliştirilerek mali açıdan tasarruf edilmesi amaçlanmış, kesim hattının bir bölümünde bulunan daire testerenin mevcut yerinin değişmesi ve kesim hattının 1/3 oranında kısalması neticesinde işletmeye \%42,6 oranında önemli tasarruf kazancı sağlanacağını tespit edilmiştir (Arslan vd., 2015). Yiğit (2012), darboğaz oluşturan makinelere yönelik geliştirdiği stratejiler ile toplam üretim süresini \%28 kısaltmış ve makinelerin kullanım oranlarını \%40'lara varan oranlarda yükseltmiştir. Daşçı (2010), yalın üretim tekniklerinden faydalanarak oluşturduğu senaryoların 
performans gelişimlerini Arena benzetim yazılımıyla ortaya koymuştur. Arena benzetim yazılımıyla yapılan bir diğer çalışmada da üretim sahasındaki malzeme taşıma sistemi ve alternatifleri modellenmiş, konveyör sistemlerinin kullanımının uzun dönemli daha uygun olduğu ifade edilmiştir (Kuvvetli vd., 2017).

\section{Materyal ve Metot}

\subsection{Materyal: İşletme ve Üretim Süreci}

Çalışmada materyal olarak İzmir'de faaliyet gösteren yatak, baza, başlık ve oturma grubu mobilyaları üreten bir mobilya üretim tesisinin verileri kullanılmıştır. Üretim süreçlerinde yeni teknolojileri kullanan işletme Türkiye'nin lider mobilya üreticisi olma yolunda hızla ilerlemektedir. Üretim süreci incelenen ürün, metal-masif konstrüksiyon üzerine sünger ve kumaş katmanlarından oluşmaktadır. Çalışmaya esas alınan "Baza başlığı” ürünü için genel süreç şeması şekil 1'de gösterilmektedir.

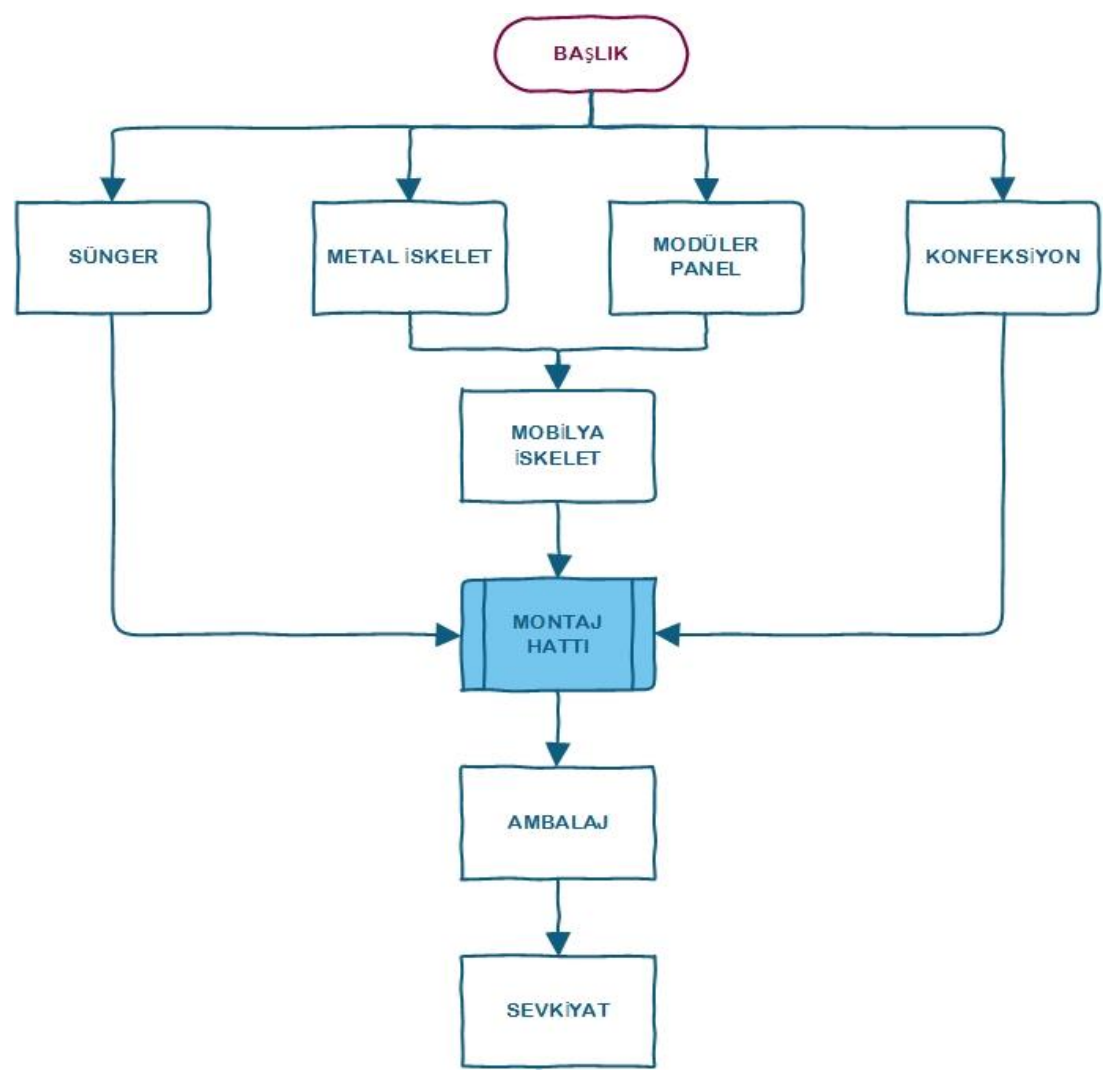

Şekil 1. Ilgili Ürüne ait Genel Süreç Şeması

Kullanılan tüm yarı mamul ihtiyaçları yurt içinden sipariş edilir, en çok kara ve deniz yoluyla tedarik sağlanır. İşletmede hammadde stok seviyeleri ve dinamik müşteri talepleri MRP planları ile takip edilmektedir. Dış sipariş temin süreleri yarı mamuller arası değişiklik görtermekle birlikte bazı dönemlerde kumaş ve sünger gibi ürünlerde 35 güne kadar çıabilmektedir. Bu durum hammadde stoklarının yüksek tutulmasını gerekli kılmaktadır.

Üretim planlama bölümü, ana üretim çizelgesini haftalık üretim planı şeklinde yapmaktadır. Planın sonlanmasıyla her bölüme haftalık üretim planı ve günlük iş emirleri (iş takip formları) gönderilmektedir. Mamul başlık üretimi için metal, mobilya iskelet, sünger, modüler panel ve konfeksiyon bölümlerindeki gerçekleştirilen faaliyetler neticesinde döşeme montaj hattı ile mamul başlık üretimi sonuçlanır. Emek yoğun olarak gerçekleştirilen işlemlerin her biri farklı iş istasyonlarında farklı operatörler tarafından gerçekleştirilir. Gizlilik gereği firmaya ve üretim süreçlerine ait ayrıntılı bilgiler çalışma içerisinde sınırlı düzeyde paylaşılmıştır. Kesikli üretim sistemiyle parti tipi üretim yapan bu işletmeye ait bilgiler, imalat atölyesi mevcut yerleşim düzeni ile imalat süreçleri ve analiz edilen ürüne ait bazı detay veriler bu çalışmanın verilerinin temin edildiği, SDÜ Fen Bilimleri Enstitüsü bünyesinde hazırlanan yüksek lisans tez içeriğinde ve bu tezden üretilerek Bilge International Journal of Science and Technology Research dergisinde yayınlanan içerikte daha kapsamlı bir şekilde verilmiştir (Karşıyaka, 2018; Karşıyaka ve Sütçü, 2019).

\subsection{Yöntem: Verimliliği Artırmaya Yönelik Uygulamalar}

Çalışma kapsamında verimlililiği artırmaya yönelik uygulamalar olarak; öncelikle iş etüdü uygulamaları başlığı altında iş-zaman etütlerinin nasıl yapıldığı, sisteme ait verilerin toplanması ve iş analizi konularına değinilmiş, ardından literatürde ve uygulamada yoğun kullanım alanı bulan benzetim ile sistemin yeniden tasarımı gerçekleştirilmiştir.

\subsection{1. İş Etüddü Uygulamaları}


İş etüdü, insan, makine ve malzeme arasında gerçekleşen tüm etkileşimleri verimliliğe dönüştürmeye çalışan, bu etkileşimleri geliştirerek işin kalitesini artıran metot etüdü ve iş ölçümü tekniklerini içeren genel bir terimdir. Her iki teknik te ayrı öneme sahiptir. Metot etüdü, maliyetleri düşürmek ve işi daha kolay yapılır hale getirebilmek için daha etkin ve kolay metotlar ile yöntemlerin geliştirilmesi, iş akışının mevcut veya önerildiği haliyle sistematik olarak kayıt edilmesi ve eleştirisel gözle incelenmesi olarak tanımlanabilir. İş ölçümü ise kalifiye bir personelin standartları tanımlı bir işi belirli bir tempo düzeyinde yerine getirebilmesi için gerekli süreyi saptamak üzere kullanılan teknikleri ifade eder (Kurt ve Dağdeviren, 2003). Metot etüdü uygulanacak süreçlerin belirlenmesinde, tercih edilen işin ekonomik değeri önemlidir. Uzun süreli ve uygulanamayacak olan işler üzerinde araştırmalar yapılması, gereksiz zaman ve emek kaybına neden olabilir. Metot etüdü uygulanacak işlerin belirlenmesinden sonra işe ait tüm bilgilerin sistematik hâlde kayıt altına alınması gerekmektedir. Bu amaçla iş akış analiz formları kullanılmaktadır.

İş etüdü çalışma süreçleri aşağıdaki gibi gerçekleşmektedir (Dal, 2010):

- İşin yapılış sürecini etkileyen çevre koşullarının ve çalışan personel ile ilgili verilerin araştırılması ve kaydedilmesi

- İşin ayrıntılı tanımlanması ve akışlarına ayrılması

- İş akışlarının ayrıntılı incelenmesi ve etkin metodun uygulandığından emin olunması

- Çalışan tarafından gerçekleştirilen her işlem zamanının ölçülmesi ve kayıt altına alınması

- Çalışanın işi yaparken tempo değerlerinin saptanması

Zaman etüdünün ilgili personel tarafından yapılabilmesi için kronometre (Süre ölçer) ve iş etüdü formları gereklidir. Çeşitli zaman etüdü formları bulunmakla birlikte bu çalışma kapsamında REFA tarafından tekrarlı iş akışları için geliştirilen Zaman Etüdü formu (Z2) kullanılmıştır (MESS-REFA, 2005). Zaman etüdü, işletmedeki 4 ayrı bölüme \%95 istataistiki güven düzeyini sağlayacak şekilde yeter sayıda örneklem yapılarak uygulanmıştır. İş sürecinde bulunan tüm faaliyetler ayrıntılı biçimde doğrudan gözlemlenerek, ve REFA zaman etüdü prosedürü uygulanarak faaliyetlere ait süreç verileri belirlenmiştir. Genel itibariyle üretim süreci; aşağıda belirtilen dört aşamada ve ayrı imalat birimlerinde gerçekleşmektedir:

- Hammadde kumaş depo işlemleri ve konfeksiyon (kumaş kesim, dikim) iş istasyonu

- Metal iskelet iş istasyonu

- Mobilya iskelet (metal-masif konstrüksiyon montajı) iş istasyonu

- Döşeme (Montaj hatt1) atölyesi

\subsubsection{Benzetim İle Sistemin Yeniden Organizasyonu}

Üretimdeki girdileri oluşturan hammadde, makine, iş gücü, zaman vb. kaynakların etkin kullanım koşulunu sağlamak için alınacak kararlar yöneticiler için oldukça önem arz etmektedir. Kaynakların ihtiyaçları ve planlamasını en etkin biçimde kullanılmasını sağlamak adına kullanılabilecek en etkili tekniklerden biri benzetim-simülasyon tekniğidir. Bu çalışmada simülasyon ve benzetim eş anlamlı olarak kullanılmıştır. Çalışma kapsamında incelenen üretim iş sürecine ait belirli bir bölümün benzetim modeli Arena programı üzerinde gerçekleştirilmiştir. Arena, Rockwell Automation tarafından geliştirilen, SIMAN modelleme dilini kullanarak girdi ve çıktı analizi araçlarına sahip, görsel ögelerle desteklenmiş bir yazılımdır. Karmaşık sistemlerin modellenmesi ve analizi için güçlü bir araçtır. Sistemin belirli bir rejim veya bir dizi parametre altında ne kadar iyi performans gösterdiğinin anlaşılmasına yardımcı olur (Altıok ve Melamed, 2007).

Arena'da üretim sistem modelinin oluşturulması için ilgili pencereleri kullanarak veri girişleri kolaylıkla gerçekleştirilebilmektedir. Bir siparişin tamamlanması sürecinde gerçekleştrilen her türlü faaliyet, bir kaynak (makine, iş istasyonu veya personel) talep etmektedir. Arena, üretim sisteminde siparişin yerine getirilmesini, birçok benzetim programlarında da görüldüğü gibi farklı iş akışlarının oluşturduğu dinamik sipariş akışı olarak ele almaktadır. Çalışmada diğer ürünler dikkate alınmayıp sadece bir tanesine ait (baza için başlık) üretim süreci modellenmiş̧ir. Bu ürünün seçilme nedeni, ilgili işletme için piyasada en çok talep gören ve sürekli üretilen ürün olmasıdır. Benzetim modelinde ihtiyaç olan hazırlık ve işlem zamanlarının belirlenmesinde iş etüdü ile elde edilen verilerden yararlanılmıştır. Veri analizi aşamasında bazı ihmaller ve varsayımlar yapılmış, sistemin stokastik benzetim modeli oluşturulmuştur.

Kurulan model için aşağıda belirtilen varsayımlar kullanılmıştır:

- Makine ve personel sayıları benzetim süresince sabittir.

- Kuyruklar teslim tarihi en erken sıralama kısıtına göre düzenlenmiş̧tir.

- Tüm iş görenler tek vardiya düzeninde günde 9 saat, haftada 45 saat çalışacak şekilde modellenmiştir.

- Makine arızaları, hatalı parçalar, yeniden işlemeler, makine ve birimler arası taşımalar göz ardı edilmiştir.

- Simülasyon koşumu 60 gün için yapılmış, koşum 3 kez tekrarlanmıştır.

- İşletmede başlı üretim sürecinde dokuz farklı iş istasyonu mevcuttur.

- Üretim miktarlarından bağımsız olarak, donanım ve iş̧̧i sayıları her istasyonda sabittir.

- Başlık üretim sürecinde tek bir ürünün üretimi yapılmaktadır.

- Üretilecek ürün, işletmenin haftalık üretim planına eklenerek sisteme girmektedir.

- Haftalık üretim planında mevcut olan sipariş miktarını karşılamak için ihtiyaç olabilecek fazla mesai ve ek vardiyalar göz ardı edilmiştir.

- Üretim sürecinde, hammadde yokluğu, makine arıza bakım faaliyetleri, işçilerin iş devamsızlığı vs. gibi sebeplerden dolayı aksamaların meydana gelmediği kabul edilmiştir. 
- Tüm iş istasyonları için iş etüdü formları doldurulmuş bu veriler dikkate alınarak iş istasyonuna ait işlem zamanları belirlenmiştir.

- İşlem zamanlarının dağılım modeli Arena tarafından üretilmiş, en düşük hata oranı veren model seçilmiş̧ir.

- İlgili ürün, kumaş, metal-masif konstrüksiyon ve depo bölümlerinden hazır gelen parçaların döşeme montaj hattında bir araya getirimesiyle imal edilmektedir. Yüzlerce modelin hangisinden kaç adet üretileceği tamamen müşteri talepleri doğrultusunda belirlenmektedir. Bu sebeple ilgili ürününün geçmiş aylara ait gerçek satış verileri kullanılarak benzetim modeli kurulmuştur (Şekil 2).

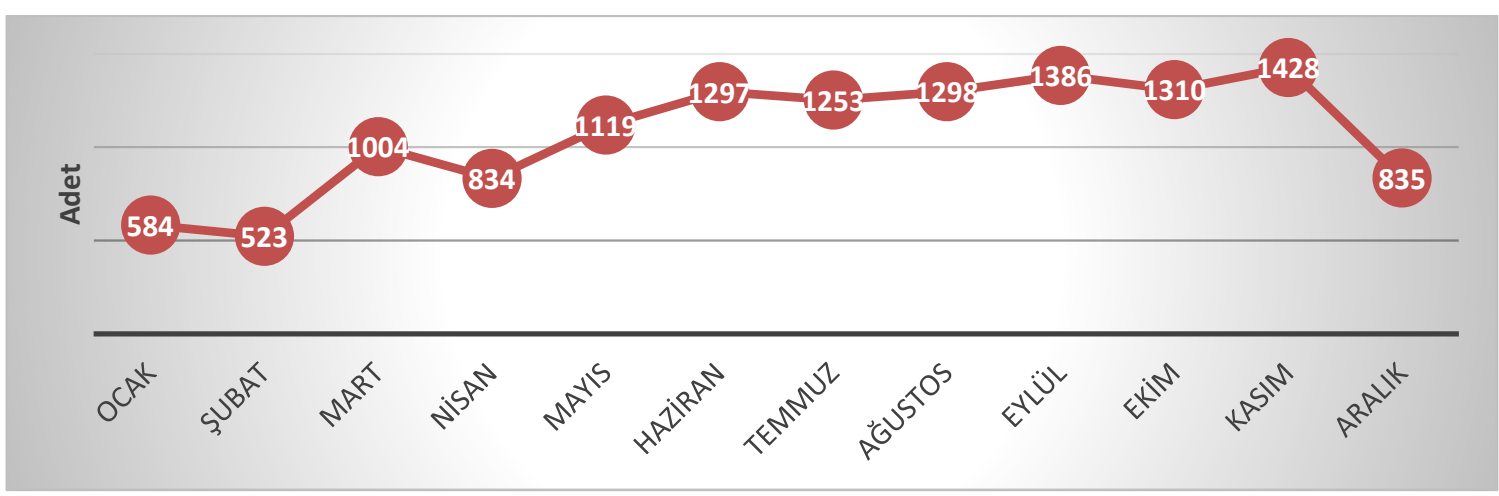

Şekil 2. İlgili Ürüne Ait Aylar İtibariyle Yıllık Talep Dă̆gllımı

Benzetim alt yapısının oluşması için gerekli verilerin yeterli oranda kayıt altında tutulması modellenecek sistemin geçerliliğini ve güvenilirliğini artıracaktır. Bu parametreler doğrultusunda üretim benzetim çıktıları göz önünde bulundurularak sistemde nasıl bir değişim veya gelişimin yaşanabileceği öngörülebilir.

\section{Araştırma Sonuçları}

\subsection{Mevcut Duruma Ait Üretim Sürecinin Analizi}

Üretim planlama departmanı, ana üretim çizelgesini haftalık üretim planı şeklinde yapmaktadır. Planın sonlanmasıyla her bölüme haftalık üretim planı ve günlük iş emirleri (iş takip formları) gönderilmektedir. Mamul başlık üretimi için bazı bölümlerde gerçekleştirilen faaliyetler aşağıda kısaca özetlenmiş ve mevcut durumda uygulanan tüm iş akışı iş analiz formu üzerinde analiz edilmiştir (Şekil 3).

Hammadde Kumaș Depo : Haftalık iş emri verilmesi ile üretilecek model için sipariş edilen kumaş topları ve hammadde giriş kalite kontrolü ile uygunluğu onaylanan kumaşlar depoda stoklanır. Burada iş emrine göre belirlenen metrajlarda kumaşlar kesilerek üretime gönderilir.

Konfeksiyon iș istasyonu: Hammadde kumaş depo alnından gönderilen kumaşların kalıplarına/ölçülerine göre serim ve kesim işlemi burada yapılmaktadır. Dikim bölümüne gidecek ürünler dikimhaneye, dikim işlemi yapılmayacak ürünler ara stoğa gönderilmektedir. İlgili mamulün dikim işlemi bulunmamaktadır.

Metal ișleme Bölümü: İş akışına göre hammadde depodan alınan profiller, faaliyet önceliğine göre üretim bölümlerine gönderilir. Belirlenen mamulün konstrüksiyonunun oluşturulabilmesi için, gerekli metal parçaların imalatı bu birimde gerçekleştirilir.

Döșeme Atölyesi: Döşeme hattı, tüm süreçlerin tamamlanıp nihai mamulün oluşturulduğu bölümdür. Döşeme yapılabilmesi için metal-masif konstrüksiyon montajı tamamlanan iskeletlerin ve diğer yarı mamullerin montaj hattına getirilmesi ile faaliyetler başlar mamul montajı burada tamamlanır. 


\begin{tabular}{|c|c|c|c|c|c|c|c|c|c|c|c|c|}
\hline \multicolumn{4}{|l|}{ IŞ AKIŞ ŞEMASI } & \multicolumn{9}{|c|}{ işçi / MALZEME / BONATI TIPI- } \\
\hline ŞEMA NO: 1 & & SAYFA NO: & & & & & & & EET & & & \\
\hline \multirow{2}{*}{\multicolumn{4}{|c|}{ KONU: BAŞLIK ÜRETIM SÜREÇLERI }} & \multicolumn{3}{|c|}{ ETKINLIK } & \multicolumn{3}{|c|}{ MEVCUT } & \multirow{2}{*}{\multicolumn{2}{|c|}{ ÖNERILEN }} & \multirow{2}{*}{ ARTIRIM } \\
\hline & & & & \multicolumn{3}{|c|}{ iŞLEM } & \multicolumn{4}{|c|}{16} & & \\
\hline \multirow[t]{2}{*}{ IŞ: MONTAJ } & & & & TAŞIM & & & \multicolumn{4}{|c|}{19} & & \\
\hline & & & & Geçici & depolan & na & & & 9 & & & \\
\hline \multicolumn{3}{|c|}{ YÖNTEM: MEVCUT / ÖNERILEN } & & Kontro & & & & & o & & & \\
\hline YER: METAL, MOB & BILYA, $\mathrm{K}$ & KONFEKSIYON, DÖŞEME ATÖLYYESI & & Depola & ama (sto & k) & & & 1 & & & \\
\hline işçi: $A, B, C, D$ & & KART NO: & & UZAKL & $\mathrm{IK}(\mathrm{m})$ & & & & - & & & \\
\hline & & & & ZAMAI & $\mathrm{N}$ (adam & 1-saat) & & & 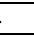 & & - & - \\
\hline ŞEMAYI ÇIZEN: & & TARIH: & & MALIY & & & & & - & & & \\
\hline & & & & işçiliı & & & & & - & & & \\
\hline ONAYLAYAN: & & TARIH: & & MALZE & EME & & & & - & & & \\
\hline & & & & TOPLA & & & & & - & & - & - \\
\hline DEPARTMAN & SIRA & TANIM & MIKTAR & Uzaklık & Zaman & & IMG & & & & AÇIKLA & AMA \\
\hline & & & & $(\mathrm{m})$ & dk. & 은 & $\Rightarrow[$ & ב & ] & $\nabla$ & & \\
\hline & 1 & KUMAȘIN DEPOYA ALINMASI & & & & & & & & & ASANSC̈ & ÖR ILE \\
\hline KUMASS DEPO & 2 & KUMAȘ METRAJ KESME & & & 0,8 & & & & & & & \\
\hline & 3 & KUMASS TOPUNUN DEPODAN GETIRILMESI & & & & & & & & & isTiF AR & ZABASI \\
\hline & 4 & ELLE SERIM VE KESIM İSLEMI & & & 0,68 & & & & & & & \\
\hline KONFEKSIYYN & 5 & PARÇALARIN ISTIFE TAȘINMASI & & & & & & & & & isTiF AR & ZABASI \\
\hline & 6 & ARA STOKTA BEKLEME & & & & & & & & & & \\
\hline & 7 & PK1 PROFILIN DEPODAN GETIRILMESI & & & 5,34 & & & & & & VINÇ & ÍLE \\
\hline & 8 & PK1 PROFIL ÇOKLU KESIM IŞLEMI & & & 0,72 & & & & & & & \\
\hline & 9 & PARÇALARIN ISTIFE TAȘINMASI & & & & & & & & & ISTiF AR & ZABASI \\
\hline & 10 & ARA STOKTA BEKLEME & & & & & & & & & & \\
\hline & 11 & PK2 PROFILIN DEPODAN GETIRILMESI & & & 5,15 & & & & & & VINÇ & ILE \\
\hline & 12 & PK2 PROFIL ÇOKLU KESIM IȘLEMİ & & & 0,66 & & & & & & & \\
\hline & 13 & ARA STOKTA BEKLEME & & & & & & & & & & \\
\hline & 14 & PARCCALARIN PRESE TASSINMASI & & & & & & & & & istiF AR & RABASI \\
\hline & 15 & PK2 PROFIL PRES ISȘLEMI & & & 0,67 & & & & & & & \\
\hline & 16 & PK2 PERÇIN İSLEMI & & & 0,55 & & & & & & & \\
\hline & 17 & PARÇALARIN ÍSTIFE TAȘINMASI & & & & & & & & & isTiF AR & ZABASI \\
\hline$\frac{1}{2}$ & 18 & ARA STOKTA BEKLEME & & & & & & & & & & \\
\hline 凷 & 19 & PK3 PROFILIN DEPODAN GETIRILMESI & & & 5,1 & & & & & & VINÇ & ILE \\
\hline$\underset{3}{\pi}$ & 20 & PK3 PROFIL ÇOKLU KESIM ISSLEMI & & & 0,58 & & & & & & & \\
\hline & 21 & PARÇALARIN ÍSTIFE TAŞINMASI & & & & & & & & & istiF AR & RABASI \\
\hline & 22 & ARA STOKTA BEKLEME & & & & & & & & & & \\
\hline & 23 & PK4 PROFILIN DEPODAN GETIRILMESI & & & 5,58 & & & & & & VINÇ & ILE \\
\hline & 24 & ARA STOKTA BEKLEME & & & & & & & & & & \\
\hline & 25 & PK4 PROFILIN BÜKÜM MAKINESINE TASSINMASI & & & & & & & & & isTiF AR & ZABASI \\
\hline & 26 & PK4 BÜKÜM İŞLEMİ & & & 0,38 & & & & & & & \\
\hline & 27 & PARÇALARIN ÍSTIFE TAȘINMASI & & & & & & & & & isTiF AR & RABASI \\
\hline & 28 & ARA STOKTA BEKLEME & & & & & & & & & & \\
\hline & 29 & PARÇALARIN ROBOTA TAȘINMASI & & & & & & & & & isTiF AR & ZABASI \\
\hline & 30 & ROBOT KAYNAK İSLEMII & & & 1,17 & & & & & & & \\
\hline & 31 & METAL ISKETLERIN ISTIFE TASSINMASI & & & & & & & & & istiF AR & RABASI \\
\hline & 32 & ARA STOKTA BEKLEME & & & & & & 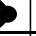 & & & & \\
\hline & 33 & HAMMADDE DEPODAN PARÇALARIN TAȘINMASI & & & & & & & & & & \\
\hline KONSTRÜKSIYY & 34 & KONSTRÜKSIYON MONTAJ ISSLEMI & & & 5,36 & & & & & & & \\
\hline ON MONTAJ & 35 & ISKELETIN ISTIFE TAŞINMASI & & & & & & & & & istiF AR & ZABASI \\
\hline & 36 & ARA STOKTA BEKLEME & & & & & & 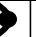 & & & & \\
\hline & 37 & ISKELETIN TASSINMASI & & & & & & & & & ISTiF AR & RABASI \\
\hline & 38 & HAMMADDE DEPODAN PARÇALARIN TAŞINMASI & & & & & & & & & ISTiF AR & ZABASI \\
\hline & 39 & KESIMHANEDEN KUMAȘLARIN GETIRILMESI & & & & & & & & & ISTIF AR & RABASI \\
\hline$\Xi$ & 40 & BEYAZLAMA & & & 0,61 & & & & & & & \\
\hline 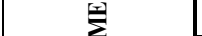 & 41 & KUMAS FONT DÖŞEME & & & 5,29 & 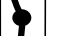 & & & & & & \\
\hline 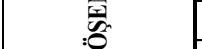 & 42 & ARKA ASTAR DÖŞEME & & & 2,12 & 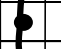 & & & & & & \\
\hline & 43 & DELIKLERIN AÇILMASI & & & 0,5 & & & & & & & \\
\hline & 44 & ISTIFE TAȘIMA & & & & & & & & & FORKLIF & FT ILE \\
\hline & 45 & SEVKIYAT DEPO & & & & & & & & & & \\
\hline & & Toplam & & & 41,26 & \begin{tabular}{|l|l}
16 & 1 \\
\end{tabular} & & 9 & 0 & & & \\
\hline
\end{tabular}

Şekil 3. İlgili Ürünün Üretim Sürecine Ait Mevcut Durumu Gösterir İ̧s Akış Analiz Formu

Çalışma kapsamında değerlendirilen ürüne ait iş akışı Şekil 4'de, zaman etüdü verileri Tablo 1'de verilmiştir. Burada ifade edilen ve özetlenen veriler, sistemin benzetim ile yeniden organizasyonu için kullanılan ham veriler olmuştur. 


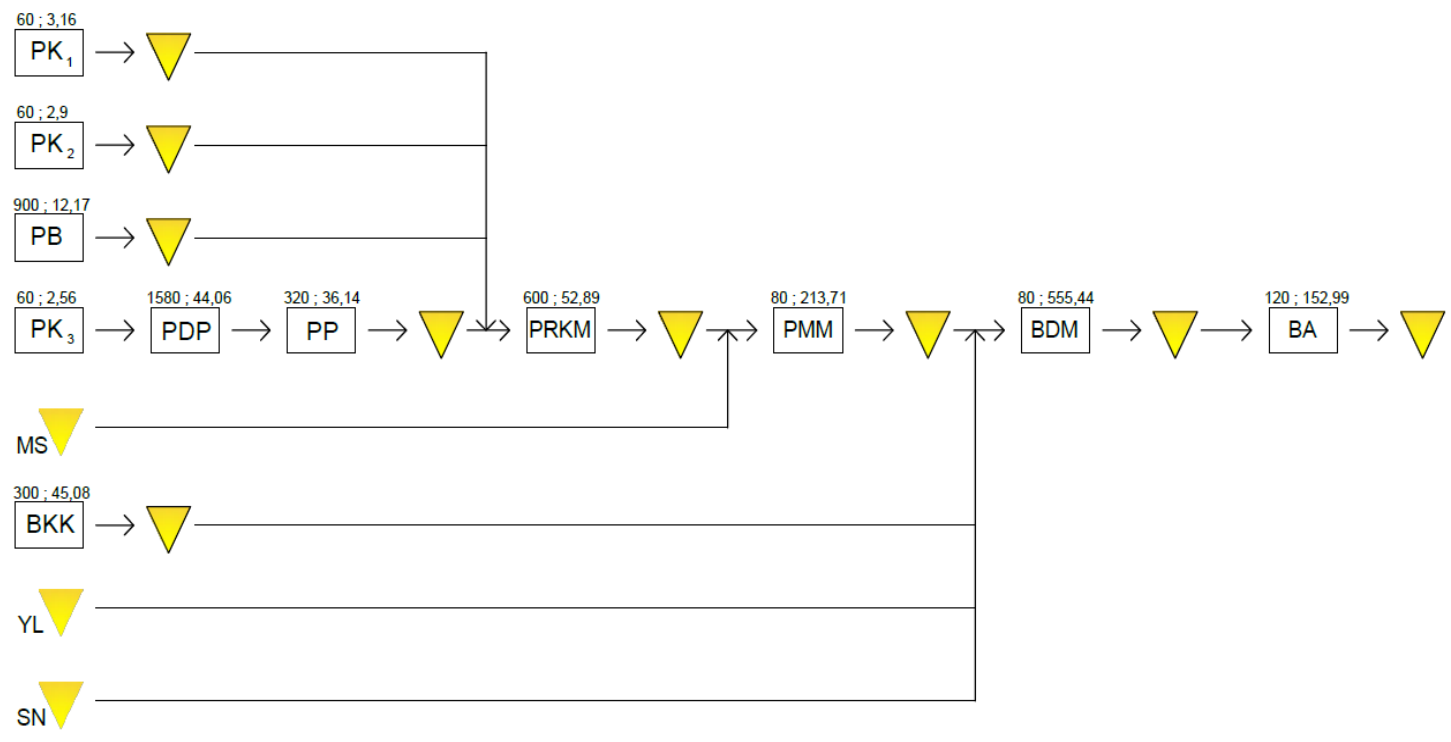

Şekil 4. İlgili Ürüne Ait Üretim İş Akışl

Tablo1. İlgili Ürün İçin Faaliyetler ve Zaman Verileri

\begin{tabular}{cclccc}
\hline Faaliyetler & Personel Sayısı & \multicolumn{1}{c}{ Faaliyet Tanımları } & tr (sn) & te (sn) & s (sn) \\
\hline PK1 & 1 & Profil kesim & 60 & 3,16 & 1,85 \\
PK2 & 1 & Profil kesim & 60 & 2,90 & 2,64 \\
PK3 & 1 & Profil kesim & 60 & 2,56 & 1,81 \\
PB & 1 & Profil bükme & 900 & 12,17 & 2,05 \\
PDP & 1 & Profil delik pres & 1580 & 44,06 & 2,59 \\
PP & 1 & Profil perçin & 320 & 36,14 & 3,38 \\
PRKM & 3 & Robot kaynak montaj & 600 & 52,89 & 1,96 \\
PMM & 6 & Mobilya iskelet montaj & 80 & 213,71 & 21,36 \\
BKK & 1 & Kumaş kesim & 300 & 45,08 & 2,57 \\
BDM & 6 & Döşeme montaj & 80 & 555,44 & 27,17 \\
BA & 1 & Ambalaj & 120 & 152,99 & 4,14 \\
\hline
\end{tabular}

tr: Hazırlık zamanı, te: İşlem zamanı, s: Standart sapma

\section{2. İş Akış Analizi İle Üretim Sürecinin İyileştirilmesi}

İlgili üretim süreci için iş analizi ile elde edilen bu veriler metot etüdü ve sistemin benzetim ile yeniden organizasyonu amacıyla kullanılmıştır. Mevcut yapı üzerinde metot etüdü yapılarak sürecin yeniden düzenlenmiş hâli ise Şekil 5'de verilmiştir. Sürecin yeniden düzenlenmesinde kullanılan yaklaşımlar: 1-İşin tamamlanmasında katma değer üretmeyen faaliyetlerin ortadan kaldırılması, ve/veya İşin bünyesinde bulunan faaliyetlerin veya iş elemanlarının; 2- birleştirilmesi, 3- yapılış sırasının değiş̧irilmesi, 4basitleştirilmesi, olarak kısaca ifade edilebilir (Kurt ve Dağdeviren, 2003). Bu uygulamalar sonucunda, mevcut durumda takip edilmesi gereken 16 işlem, önerilen sistemde 11 işleme düşürülmüştür (Şekil 5). 
Avrupa Bilim ve Teknoloji Dergisi

\begin{tabular}{|c|c|c|c|c|c|c|c|c|c|c|c|}
\hline \multicolumn{4}{|l|}{ IŞ AKIŞ ŞEMASI } & \multicolumn{8}{|c|}{ işȩi / MALZEME / DONATITiPi } \\
\hline \multirow{2}{*}{\multicolumn{4}{|c|}{$\begin{array}{l}\text { ŞEMA NO: } 1 \\
\text { KONU: BASLIK ÜRETIM SÜRECLERI }\end{array}$}} & \multicolumn{8}{|c|}{ ÖZET } \\
\hline \multirow{2}{*}{\multicolumn{3}{|c|}{ KONU: BAŞLIK ÜRETIM SÜREÇLERI }} & & \multicolumn{3}{|c|}{ ETKINLIK } & \multirow{2}{*}{\multicolumn{3}{|c|}{ MEVCUT }} & \multirow{2}{*}{\begin{tabular}{|c|} 
ÖNERILEN \\
11 \\
\end{tabular}} & \multirow{2}{*}{\begin{tabular}{|l} 
ARTIRIM \\
5 \\
\end{tabular}} \\
\hline & & & & IŞLEM & & 0 & & & & & \\
\hline \multirow[t]{2}{*}{ IŞ: MONTAJ } & & & & \multicolumn{3}{|l|}{ TAŞIMA } & \multicolumn{3}{|c|}{19} & 16 & 3 \\
\hline & & & & \multicolumn{3}{|c|}{ Geçici depolama $\quad \mathrm{D}$} & \multicolumn{3}{|c|}{9} & 5 & 4 \\
\hline \multicolumn{3}{|c|}{ YÖNTEM: MEVEUT / ÖNERILEN } & & \multicolumn{3}{|c|}{ Kontrol $\quad \square$} & \multicolumn{3}{|c|}{0} & 0 & 0 \\
\hline \multicolumn{3}{|c|}{ YER: METAL, MOBILYA, KONFEKSIYON, DÖŞEME ATÖLYESI } & & Depolama (sto & ok) & & & 1 & & 1 & 0 \\
\hline işçi: $A, B, C, D$ & & KART NO: & & UZAKLIK $(\mathrm{m})$ & & & & - & & & \\
\hline & & & & ZAMAN (adam & n-saat & & & - & & - & - \\
\hline ŞEMAYI ÇIZEN: & & TARIH: & & MALIYET & & & & - & & & \\
\hline & & & & işçiLikik & & & & - & & & \\
\hline ONAYLAYAN: & & TARIH: & & MALZEME & & & & - & & & \\
\hline & & & & TOPLAM & & & & - & & - & - \\
\hline DEPARTMAN & SIRA & TANIM & MIKTAR & UzaklıkZaman & & sime & GE & & & AC्|KL & AMA \\
\hline & No & & & \begin{tabular}{|l|l|}
$(\mathrm{m})$ & $\mathrm{dk}$. \\
\end{tabular} & 0 & $\Rightarrow$ & $\mathrm{D}$ & 만 & $\bar{\nabla}$ & & \\
\hline & 1 & KUMAŞIN DEPOYA ALINMASI & & & & & & & & ASANSC̈ & ÖR İLE \\
\hline $\begin{array}{l}\text { HAMMADDE } \\
\text { KUMAS DEPO }\end{array}$ & 2 & KUMAŞ METRAJ KESME & & 0,8 & & & & & & & \\
\hline & 3 & KUMAŞ TOPUNUN DEPODAN GETIRILMESI & & & & & & & & isTiF AR & RABASI \\
\hline & 4 & ELLE SERIM VE KESIM IŞLEMI & & 0,68 & & & & & & & \\
\hline KONFEKSIYON & 5 & PARÇALARIN İSTIFE TAŞINMASI & & & & & & & & ISTiF AR & RABASI \\
\hline & 6 & ARA STOKTA BEKLEME & & & & & & & & & \\
\hline & 7 & PK2 PROFILIN DEPODAN PRESE GETIRILMESI & & 5,15 & & & & & & isTiF AR & ZABASI \\
\hline & 8 & PK2 PROFIL PRES İŞLEMİ & & 0,67 & & & & & & & \\
\hline & 9 & PK2 PERÇIN IȘLEMI & & 0,55 & & & & & & & \\
\hline & 10 & PARÇALARIN ISTIFE TAŞINMASI & & & & & & & & ISTiF AR & ZABASI \\
\hline & 11 & ARA STOKTA BEKLEME & & & & & & & & & \\
\hline$\frac{5}{Z}$ & 12 & PK4 PROFILIN DEPODAN GETIRILMESI & & 5,58 & & & & & & VINÇ & İLE \\
\hline I & 13 & PK4 PROFILİN BÜKÜM MAKİNESINE TAŞINMASI & & & & & & & & ISTIF AR & RABASI \\
\hline$\underset{t}{t}$ & 14 & PK4 BÜKÜM İşLEMI & & 0,38 & & & & & & & \\
\hline & 15 & PARÇALARIN ISTIFE TAȘINMASI & & & & & & & & ISTiF AR & ZABASI \\
\hline & 16 & ARA STOKTA BEKLEME & & & & & & & & & \\
\hline & 17 & P1,P2,P3,P4 PARÇALARIN ROBOTA TAȘINMASI & & & & & & & & ISTiF AR & ZABASI \\
\hline & 18 & ROBOT KAYNAK IȘLEMİ & & 1,17 & & & & & & & \\
\hline & 19 & METAL ISKETLERIN ISTIFE TAȘINMASI & & & & & & & & ISTiF AR & ZABASI \\
\hline & 20 & ARA STOKTA BEKLEME & & & & & & & & & \\
\hline & 21 & HAMMADDE DEPODAN PARÇALARIN TAȘINMASI & & & & & & & & & \\
\hline KONSTRÜKSIYY & 22 & KONSTRÜKSIYON MONTAJ IȘLEMI & & 5,36 & & & & & & & \\
\hline ON MONTAJ & 23 & İSKELETIN İSTIFE TAȘINMASI & & & & & & & & ISTiF AR & ZABASI \\
\hline & 24 & ARA STOKTA BEKLEME & & & & & & & & & \\
\hline & 25 & İSKELETIN TAŞINMASI & & & & & & & & ISTiF AR & RABASI \\
\hline & 26 & HAMMADDE DEPODAN PARÇALARIN TAȘINMASI & & & & 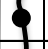 & & & & ISTiF AR & RABASI \\
\hline & 27 & KESIMHANEDEN KUMAȘLARIN GETIRILMESI & & & & & & & & ISTiF AR & RABASI \\
\hline 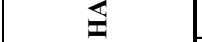 & 28 & BEYAZLAMA & & 0,61 & & & & & & & \\
\hline$\sum^{5}$ & 29 & KUMAȘ FONT DÖȘEME & & 5,29 & P & & & & & & \\
\hline$: 0$ & 30 & ARKA ASTAR DÖȘEME & & 2,12 & 9 & & & & & & \\
\hline & 31 & DELiKLERIN AÇILMASI & & 0,5 & & & & & & & \\
\hline & 32 & İSTIFE TAȘIMA & & & & & & & & FORKLIF & FT ILE \\
\hline & 33 & SEVKIYAT DEPO & & & & & & & & & \\
\hline & & Toplam & & 28,86 & 11 & 16 & 5 & 0 & 1 & & \\
\hline
\end{tabular}

Şekil 5. Üretim Sürecine Ait Metot Etüdü Sonrası Önerilen Durum Işs Akış Analiz Formu

İş analizi ile gerçekleştirilen faaliyetler sonucu ilgili üretim sürecine ait önemli düzeyde zaman kazancı elde edilmiş, üretim temin süresi \%30 azaltılarak 41,26 dk'dan 28,86 dk'ya, işlemlerin sayısı 16'dan 11'e, taşımaların sayısı 19'dan 16'ya, geçici depolama (süreç içi stok) 9'dan 5'e düşürülmüştür. Böylece sistem etkinliği ve verimliliği yükselmiş̧tir.

İşletmede çalışmaya esas ilgili ürün ile birlikte onlarca benzer ürün, yüzlerce bileşen üretilmektedir. Gerçekleştirilen bu iyileştirmeler aynı şekilde diğer bileşenlere de kolaylıkla uyarlanabilmektedir. Bununla birlikte; ilgilenilen ürünün üretim sürecini 
etkilemese de kanepe ve berjer ürünlerinin üretim süreçlerini doğrudan ilgilendiren bazı iyileştirme uygulamaları, konfeksiyon iş istasyonu ve mobilya iskelet montaj brimleri için aşağıda kısaca açıklanmıştır.

\subsection{Konfeksiyon Bölümünde Gerçekleştirilen Örnek İyileştirme Uygulamaları}

Dikişli ürünler için otomatik kumaş serim ve kesim işlemi ile başlayan konfeksiyon üretim sürecini takip eden diğer faaliyet ise, dikilmesi gereken parçaların çizim işlemidir. Konfeksiyon montaj hattında hem hatasız dikim hem de verimli üretim için yapılan çalışmaların öncesinde kritik parçaların çizim işlemi gelmektedir. Kesimi biten kumaşların önceden hazırlanmış kalıplar aracılığıyla çizgi taşı ile referans yerleri çizilmektedir. Bu iş istasyonunda, gerçekleştirilen metot etüdü ve iş analizleri sonucu, katma değersiz faaliyetlerin ortadan kaldırılması ve iş birleştirme gibi yeniden organizasyon faaliyetleri ile proses verimliliği açısından önemli bir kazanım elde edilmiştir. Şöyle ki; ilgili iş istasyonunda bilgisayar kontrollü sayısal tezgâhta (Çoklu kumaş kesim- CNC) mevcut kesim yapılırken, çizilecek parçalara aynı anda küçük delikler açılması sağlanmış, böylece manuel çizim faaliyeti ortadan kaldırılmıştır (Şekil 6). Makine üzerinde yapılacak düzenleme için makine firmasıyla görüşmeler gerçekleştirilmiş ve makinenin istenilen faaliyeti gerçekleştirecek şekilde uyarlaması yapılmışır. Sonuçta kumaş kesimi yapıllırken aynı zamanda delik delme işlemi de gerçekleştirilebilir olmuş, kesim sonrası çizgi taşıyla manuel çizim yapılma faaliyeti ortadan kaldırılmıştır. Böylece konfeksiyon bölümünün ilgili iş istasyonunda, modellerin faaliyet süresi açısından $\% 100$ 'den $\% 5$ 'e kadar değişmekle birlikte ortalama $\% 38$ 'lik bir kazanç elde edilmiştir (Tablo 2).

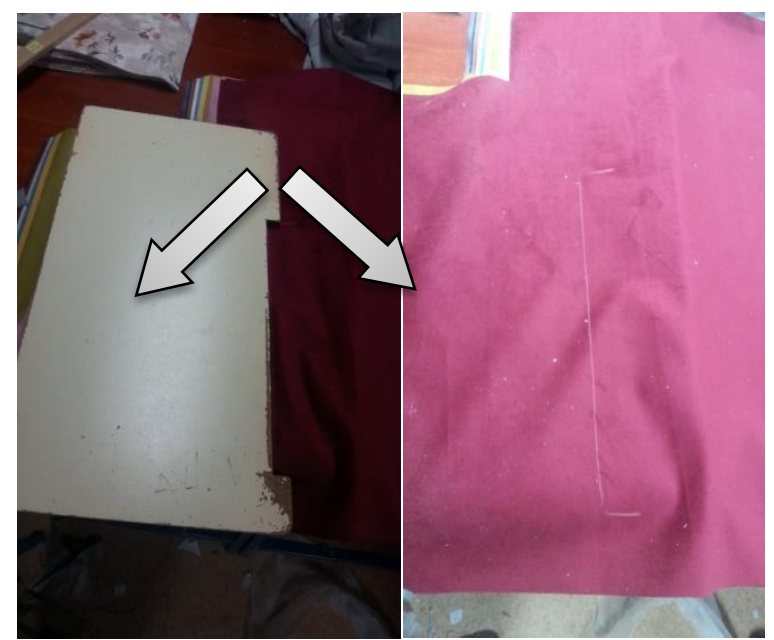

(a)

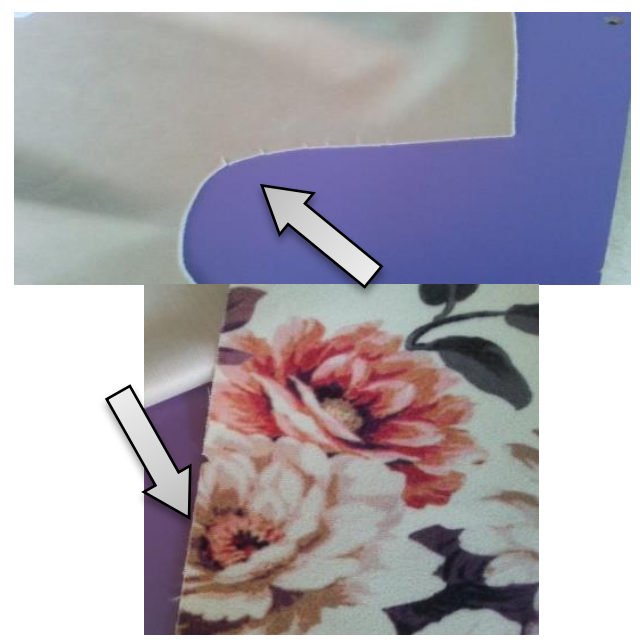

(b)

Şekil 6. Kumaş Kesim Bölümünde Metot Etüdü Uygulaması. Öncesi Durum (a), Sonrası Durum (b)

Tablo 2. Konfeksiyon Bölümünde Uygulanan Metot Etüdü Sonrası Kazanç Tablosu

\begin{tabular}{cllcccc}
\hline Model & Modül & Uygulama & Önce (sn) & Sonra (sn) & Kazanç (sn) & Kazanç (\%) \\
\hline Model 1 & Berjer & Kol kavisine çıt atımı & 323 & 235 & 88 & 27,24 \\
Model 2 & Kanepe & Oturum birleşimine çizim işlemi & 29 & 0 & 29 & 100,00 \\
Model 3 & Kanepe & Kırlent (çizim işlemi) & 24 & 0 & 24 & 100,00 \\
Model 4 & Berjer & Ped bölümüne çıt atımı & 1110 & 1058 & 52 & 4,68 \\
Model 5 & Kanepe & Oturum minderine çıt atımı & 362 & 316 & 92 \\
Model 6 & Kanepe & Sırt minderine çıt atımı & 240 & 209 & 31 \\
Model 7 & Kanepe & Kol bölümüne çıt atımı & 295 & 260 & 70 \\
Model 8 & Kanepe & Kol bölümüne çıt atımı & 296 & 270 & 52 \\
\hline
\end{tabular}

\subsection{Mobilya İskelet Montaj İş İstasyonunda Gerçekleştirilen Örnek İyileştirme Uygulamaları}

İşletmeye gelen bazı yarımamül parçalar ön işlemlerden geçirilerek üretime alınmaktadır. Bu malzemelerin tedarikçileri ile yapılacak görüşmeler sayesinde çoğu zaman ek bir maliyete dahi katlanmadan bazı işlemlerin tedarikçide yapılması sağlanabilir. Örneğin çalışma yapılan işletmede, bazı parçalar için tedarikçi firma yetkilileri ile görüşmeler yapılmış, teknik çizimler paylaşılarak siparişlerin montaj delikleri açılmış hâliyle temin edilmesi sağlanmıştır (Şekil 7).

Sonuçta kayın kaplı lif levhanın tedarikçide CNC makine ile kesimi yapılırken aynı zamanda delik delme işlemi de gerçekleştirilebilmiş, bu durum tedarikçi firma için katlanılabilir bir maliyet ve süre oluşturduğu için tedarikçi tarafindan da kabul edilmiştir. Böylece süreç içi kalite kayıpları ve değer katmayan taşıma faaliyetleri ortadan kaldırılmıştır. 


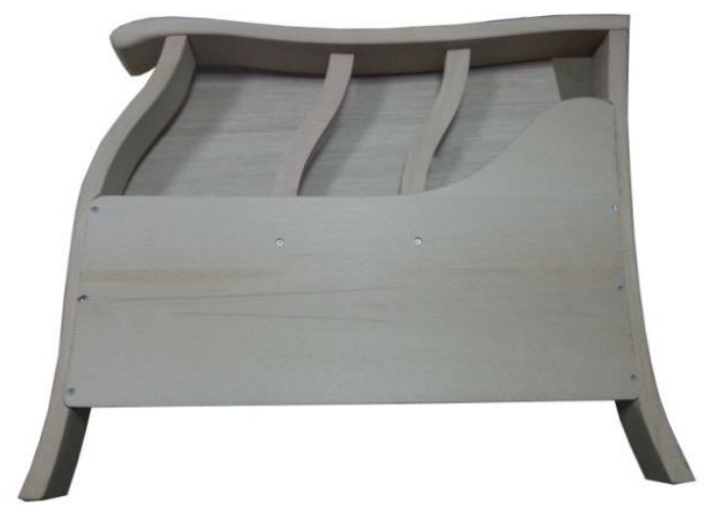

(a)

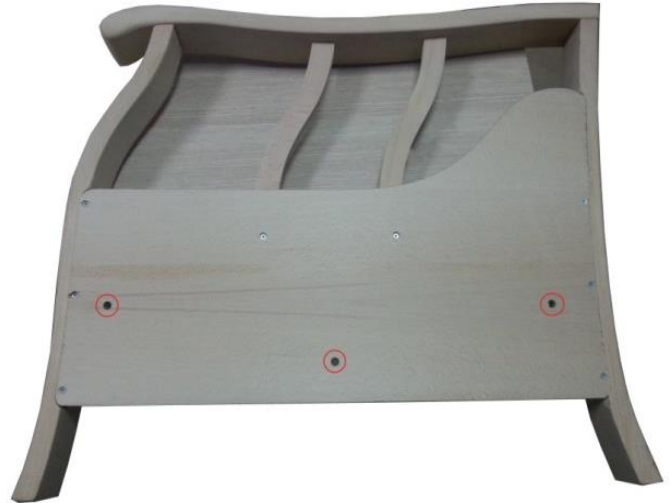

(b)

Şekil 7. Mobilya İskelet Bölümünde Uygulanan İyileştirme Faaliyetleri. Öncesi Durum (a), Sonrası Durum (b)

\section{5. Üretim Sürecinin Benzetim ile Yeniden Düzenlenmesi}

Öncelikle mevcut durum modellenmiş, ardından önerilen değişikliklerle söz konusu üretimin nasıl daha verimli hâle getirilebileceği araştırılmıştır. Sistemin benzetim modeli için öncelikle Arena 14.0 programı içeriğinde olan Input Analyzer'dan faydalanılarak her bir faaliyete ait iş-zaman değerlerinin dağılımları belirlenmiştir. Bu amaçla; iş akış planındaki faaliyetler text dosyası uzantısı ile kayıt edilerek, her bir işleme ait zaman etüdü verileri yardımıyla histogramlar oluşturulmuştur. "Fit all" sekmesi ile bu değerlerin hangi dağılıma uyduğu analiz edilmiş̧tir. Input Analyzer aracıllğ̆yla otomatik gerçekleştirilen ki-kare testi sonuçları ile ana proses dağılım oranlarını karşılayıp karşılayamadığı test edilmiştir. Test sonucunda $p>0,05$ olması sebebiyle elde edilen sonuçların ana proses dağılım oranları arasında farklılıkların olmadığı kanatine varılmıştır. Şekil 8'de PM-5 faaliyetinin işlem süresine ait dağılım histogramı ve dağılıma ait tanımlayıcı istatistikler verilmiştir.
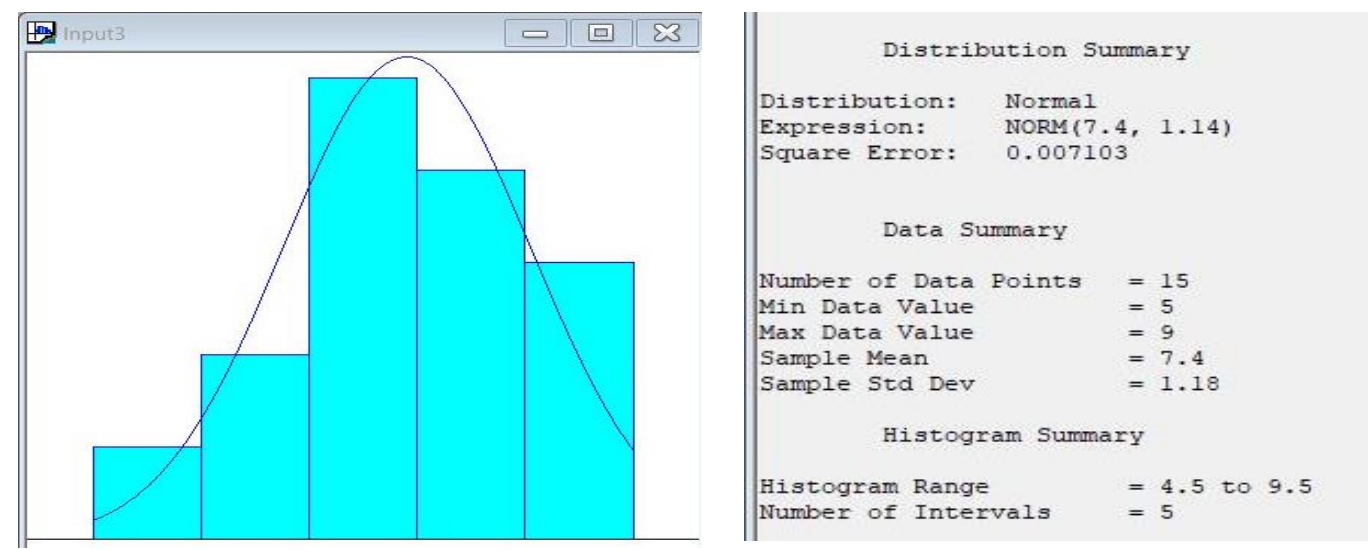

Şekil 8. PM-5 İşlemine Ait İslem Zamanı Dağıllımı ve Tanımlayıcı İstatistikler

Tüm faaliyetlerin süre dağılımları belirlendikten sonra mevcut işleyişi gösteren benzetim modeli Arena 14.0 paket programı öğrenci versiyonu kullanılarak oluşturulmuştur. Veriler girildikten sonra mevcut durumun benzetim koşumu gerçekleştirilmiş, performans değerlerinin hesaplanması sağlanmıştır. Simulasyon modelinin kontrolu için Arena 14.0 paket programında model akışının kontrolu, varlıkların doğru kısım ve zamanda oluşturulması, mantıksal hataların aranması ve kaynakların varlık kullanımından sonra serbest bırakılması modelin kontrolu aşamasında yapılan işlemlerdir. Modelin doğrulanmasının ise kolay yöntemi model sistemin uzmanı nezaretinde kontrol edilir, gerçek sistemin çıktıları simulasyon sonuçları ile karşılaştırılır (Rosetti, 2010).

Mevcut durumun benzetim modeline ait animasyon grafiği Şekil 9'da gösterilmiştir. 


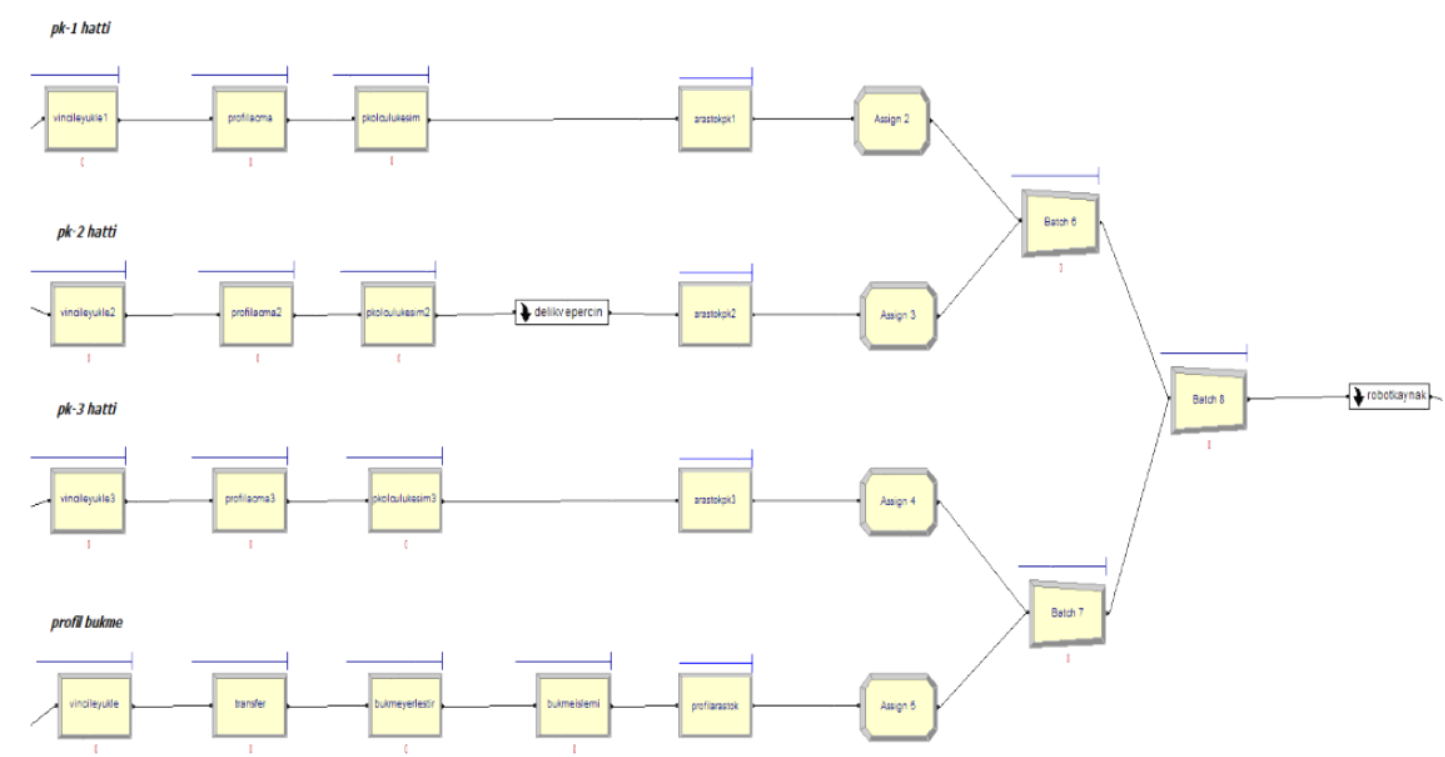

Şekil 9. Metal İşleme Bölümü Mevcut Durum Benzetim Modeli

Mevcut benzetim modelin 17 adet iş istasyonu ve 2 adet "perçin ve delik" ve "robot kaynak" alt montaj işlemi yer almaktadır. Önerilen sistemin benzetim modelinde değer katmayan faaliyetler kaldırılarak iş istasyonu sayısı beş’e indirgenmiştir (Şekil 10).

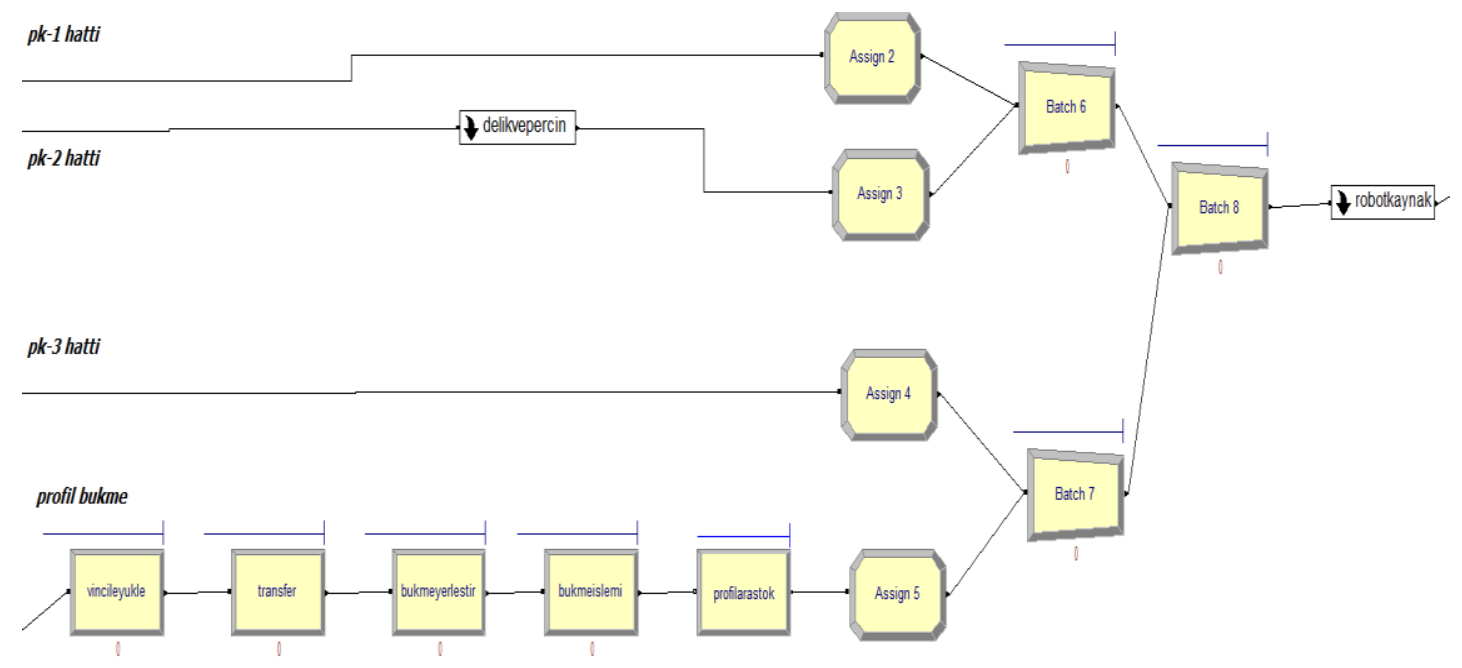

Şekil 10. Metal İsleme Bölümü Önerilen-Alternatif Durum Benzetim Modeli

Benzetim modeli ile izlenen ilgili iş akış süreci için tüm iş istasyonlarına ait kapasite kullanım oranlarındaki değişim Tablo 3'de verilmiştir. 
Tablo 3. Modellenen Üretim Sürecine Ait İ̧̦ İstasyonlarındaki Kapasite Kullanım Oranı Değişimi

\begin{tabular}{lccc}
\hline Kaynaklar & Mevcut Model (\%) & Önerilen Model (\%) & Değişim $(|\boldsymbol{\Delta}| \mathbf{)}(\mathbf{\%})$ \\
\hline Ambalaj & 52,41 & 53,08 & 0,67 \\
Profil Büküm & 1,34 & 1,34 & 0,00 \\
Profil Çoklu Kesim & 13,51 & İşlem kaldırıldı & 13,51 \\
Kumaş Kesim & 15,78 & 15,77 & 0,01 \\
Çoklu Kesim Operatör & 3,44 & İşlem kaldırıldı & 3,44 \\
Perçin & 36,57 & 36,71 & 0,14 \\
Press & 7,83 & 7,83 & 0,00 \\
Profil Büküm Operatör & 1,77 & 1,78 & 0,01 \\
İskelet Personel_1 & 51,23 & 52,02 & 0,79 \\
İskelet Personel_2 & 51,23 & 52,02 & 0,79 \\
İskelet Personel_3 & 51,23 & 52,02 & 0,79 \\
İskelet Personel_4 & 51,23 & 52,02 & 0,79 \\
İskelet Personel_5 & 51,23 & 52,02 & 0,79 \\
İskelet Personel_6 & 51,23 & 52,02 & 0,79 \\
Robot Kaynak_1 & 4,06 & 3,13 & 0,93 \\
Robot Kaynak_2 & 0,13 & 1,18 & 1,05 \\
Robot Operatör_1 & 7,79 & 5,24 & 2,55 \\
Robot Operatör_2 & 1,88 & 2,62 & 0,74 \\
Robot Operatör_3 & 0,54 & 2,63 & 2,09 \\
Vinç & 0,16 & 0,04 & 0,12 \\
\hline
\end{tabular}

Bu sonuçlara göre; mevcut durumda 6485 adet baza başlığı üretilirken, önerilen durumla 6569 adet çıktıya ulaşılmıştı. Böylece yaklaşı \% 1,3 'lük verimlilik (üretkenlik) artışı sağlanmıştır. Ancak perçin ve pres faaliyetlerinde üretilen miktar değişmediği için değişiklik gözlemlenmemiştir. Aynı zamanda başlık üretim çevrim zamanı 389 dk'dan, 355 dk'ya düşerek yaklaşık 34 dk kazanç sağlanmış olup üretim verimliliğinde \%10'luk artışa tekabül etmektedir. Kapasite kullanımında önemli kazançlar elde edilmiştir. Şöyle ki; mevcut durumda çoklu kesim faaliyeti yapılırken, önerilen durumda bu faaliyet kaldırılarak $\% 13,5$ ve operatör kullanımında da \%3,4'lük kazanç elde edilmiştir. Buna istinaden hammadde depodan çoklu kesim tezgâhına taşıma faaliyeti mevcut durumda $\% 0,16$ kullanılırken, önerilen durumda \%0,04'e azaltılarak \%0,12'lik kazanca ulaşılmıștır. Bunlarla birlikte, kullanılmayan kapasitekaynaklar diğer ürünlerin üretimine aktarılarak toplam işletme verimliliğinde de önemli kazançların elde edileceği aşikârdır.

\section{Sonuç ve Tartışma}

Uygulama araştırması olarak gerçekleştirilen bu çalışma ile; ahşap iskeletli döşemeli mobilya imalatı yapan orta ölçekli bir üretim tesisindeki tüm üretim süreci iş etüdü uygulamaları ile analiz edilmiş, seçilen bir ürüne ait üretim süreci Arena 14.0 benzetim yazılımı ile modellenmiştir. İş etüdü uygulamaları ile, ilgili üretim sürecine ait önemli düzeyde zaman kazancı elde edilmiş, üretim temin süresi \%30 azaltılarak 41,26 dk'dan 28,86 dk'ya, işlemlerin sayısı 16'dan 11'e, taşımaların sayısı 19'dan 16'ya, geçici depolama 9'dan 5'e düşürülmüştür. Geliştirme modelleri olarak metal atölyesine ait iş ve işlemlerde yeniden organizasyon çalışmaları yapılmış, süreç içi stok seviyeleri düşerken zamanında teslim edilebilir sipariş sayılarında artış olmuştur. Aynı zamanda çevrim zamanı düşürülerek üretim verimliliğinde yaklaşık \%10'luk artış sağlanmıştır. Benzetim ile mobilya işletmelerinde verimliliğin artırılması konusunda doğrudan veya dolaylı yapılmış benzer çalışmalarda da önemli kazanımların çok daha kısa sürelerde ve düşük maliyetlerle elde edilebildiği, literatürde kapsamlı bir şekilde ortaya konulmaktadır (Akın, 2015; Arslan vd., 2015; Daşç1, 2010; Karaca, 2007; Sütçü vd., 2011; Sütçü vd., 2006; Yiğit, 2012). Bu araştırmada kullanılan benzetim modeli, sadece bu çalışmanın amacı doğrultusunda kullanılmayıp, aynı zamanda fabrikada devam eden faaliyetleri aksatmadan sanal bir sistem üzerinde değişiklikler uygulayarak deneme yapma imkanı sunmaktadır. Böylece farklı senaryoları deneyerek performans karşılaştırması yapılabilir ve üretim planları daha etkin bir şekilde uygulanabilir.

Benzetim yöntemi sayesinde, yeniden organizasyon faaliyetlerinin atölye ortamında birebir uygulaması yapılmadan bilgisayar üzerinde performans değerlerinin izlenebilmesi ve beklenen iyileştirmeyi sağlayıp sağlamadı̆̆ının testine yönelik literatürde çok sayıda çalı̧̧ma bulunmaktadır (Nyemba ve Mbohwa, 2017; Ali ve Zulkifli, 2017; Silva vd., 2017; Rahman vd., 2019). Ancak üretim ortamlarının kendine has özellikler taşıması her bir firma için yapılan yeniden organizasyon faaliyetlerinin orijinalliğini oluşturmaktadır. $\mathrm{Bu}$ çalışma ile verimliliğin arttırılması ve rekabetin öncelik edinebilmesi adına gerçekleştirilen bu uygulamalar, örnek teşkil etmesi açısından büyük bir öneme sahiptir. Çalışmada örneklendirilen verimliliği arttırmaya yönelik faaliyetler, ülkemiz mobilya endüstrisinde doğrudan ve benzer diğer sektörlerde adaptasyon yöntemiyle uygulanılarak önemli kazanımlar elde edilebilecektir. Kurumsallaşma faaliyetlerine devam eden işletmede gerçekleştirilen bu iyileştirmeler, bütünü görebilen eğitimli kalifiye personeller vasitasiyla olabilmektedir. 
Çalışmadaki kısıtlar ve karşılaşılan zorluklar nedeniyle tüm ürünlere ait süreçlerin benzetim modelleri oluşturulamamış, ancak diğer üretim süreçleri için de iyileştirme uygulamaları yapılmış ve çalışma içerisinde bunlara da yer verilmiştir. Benzetim ile ilgili olarak en büyük kısıtımız akademik versiyonu kullanılan benzetim yazılımıdır. Bununla birlikte mobilya sektöründeki ürün çeşitliliğinin fazla olması, zaman kısıtlılığı ve maliyetler de çalışma esnasında karşılaşılan önemli zorluklar olmuştur. Bu zorluklarakısıtlara rağmen çalışma kapsamında ilgili iş istasyonları ve üretim süreçleri olabildiğince kapsamlı bir şekilde incelenmiş, verimlilik artırımına yönelik geliştirilen önerilerin büyük kısmı uygulamaya geçirilerek kazanımlar atölye ortamında doğrudan tecrübe edilmiştir.

\section{Kaynakça}

Akın, N.G. (2015). Kanepe Montaj Hatııın Dengelenmesi ve Benzetim Yöntemi İle Sınanması. Çankırı Karatekin Üniversitesi İIBF Dergisi, 5(1): 95-120.

Ali, A.T.B., Zulkifli, M.F., (2017). A study on the cycle time of an assembly workstation using application of arena simulation software in a furniture industry, Proceedings of the International Conference on Industrial Engineering and Operations Management, 2017 (JUL, 2017):67-76.

Altıo, T., Melamed, B., (2007). Simulation Modeling and Analysis with Arena. Elsevier Academic Press, Amsterdam.

Arslan, H.M., Yıldız, M.S., Uysal, H.T., (2015). Kesim Hattında Süreç İyileştirme ve Etkin Tasarruf: Ağaç İşleri Atölyesine Yönelik Bir Uygulama. Zeitschrift Für Die Welt Der Türken, Journal Of World Of Turks, 7:121-136.

Dal, V., (2010). Refa, Mtm ve Gsd İş Akış Süresi Belirleme Sistemlerinin Örnek Bir Uygulama İle Karşılaştırılmalı Olarak İncelenmesi. Türk Bilim Araştırma Vakfi, Tubav Bilim Dergisi, 3(3):224-237

Daşc1, A., (2010). Benzetim Destekli Yalın Üretim Sisteminin Mobilya Sektöründe Uygulaması. Erciyes Üniversitesi Fen Bilimleri Enstitüsü Yüksek Lisans Tezi, 100s., Kayseri.

Dizdar E. N., Özen, R., (2001). Ahşap Mobilya Endüstrisinde Üretim Verimliliği İçin İş Etüdü Uygulamaları. Teknoloji, (1-2):1-9

Karaca, S., (2007). Benzetim Modellemesi İle Mobilya Üretiminde Sistem Analizi ve Optimizasyonu. Zonguldak Karaelmas Üniversitesi Fen Bilimleri Enstitüsü Doktora Tezi, 126 s., Bartın.

Karşıyaka, O., (2018). Bir Mobilya Fabrikasının Verimliliğini Artırmaya Yönelik Uygulamalar: Üretim Sisteminin Yeniden Organizasyonu. Süleyman Demirel Üniversitesi Fen Bilimleri Enstitüsü Yüksek Lisans Tezi, 78s., Isparta

Karşıyaka, O., Sütçü, A. (2019). Mobilya Üretim Süreçlerinde Verimliliği Artırmaya Yönelik 5S Uygulamaları. Bilge International Journal of Science and Technology Research, 3 (2): 87-101

Kaya, A.İ., (2001). Mobilya Endüstrisinde Kapasite Planlama. Balıkesir Üniversitesi Sosyal Bilimler Enstitüsü Yüksek Lisans Tezi, 148 s, Balıkesir.

Kurt, M., Dağdeviren M., (2003). İş Etüdü. Gazi Kitabevi, Ankara.

Kuvvetli, Y., Erol, R., (2017). Ağaç Ürünleri Üreten Bir İşletmede Malzeme Taşıma Sisteminin Benzetim Yaklaşımıyla İyileştirilmesi. Çukurova Üniversitesi Mühendislik Mimarlık Fakültesi Dergisi, 32(1):215-222.

MESS-REFA, (2005). İş Sistemi ve Süreç Düzenleme, Mess Yayın No: 451, Acar Matbacıllk, İstanbul.

Nyemba, W.R., Mbohwa, C., (2017). Modelling, simulation and optimization of the materials flow of a multi-product assembling plant, Procedia Manufacturing, 8(2017):59-66.

Orsiad, (2019). Türk mobilya sektörü Fas üzerinden Batı ve Kuzey Afrika’ya açılacak. ORSIAD Orman Sanayi İş Adamları Gazetesi, 25 Haziran 2019 (www.orsiad.com.tr Erişim: 15.07.2019)

Rahman, A., Sarker, S., Islam, M.T., (2019). Simulating Cutting Line of a Furniture Industry. International Conference on Production and Operations Management Society, POMS 2018, 29 January 2019, Amaya Hills Hotel KandyKandy; Sri Lanka

Rosetti, M.D., (2010). Simulation Modeling and Arena, John Wiley \& Sons, New Jersey

Silva, A.N., Araújo, A.V., Godoy, L.C., Minette, L.J., Suzuki, J.A., (2017). Contribution of computational simulation for layout analysis in a wooden furniture industry. Revista Árvore, 2017;41(2):e410201 http://dx .doi.org/10.1590/180690882017000200001

Sutcu, A., Tanritanır, E., Durmusoglu, B., Koruca, H.I., (2011). An Integrated Methodology for Layout Design and Work Organisation In a Furniture Manufacturing Plant. South African Journal of Industrial Engineering, 22(1):183-197

Sütçü, A., Tanrıtanır, E., Eroğlu, A., Koruca, H.İ. (2006). Orman Ürünleri Endüstrisinde Benzetim Destekli Çalışmalar ve Bir Örnek Uygulama. Süleyman Demirel Üniversitesi Orman Fakültesi Dergisi, 2006 (2):141-155.

Yiğit, M.A., (2012). Bir Ofis Mobilyası Üretim Sisteminin Benzetim İle Analizi ve Optimizasyonu. Gaziosmanpaşa Üniversitesi Sosyal Bilimler Enstitüsü Doktora Tezi, 202s, Tokat. 